\title{
As três faces da latinidade: significante, repetição e recalque
}

\author{
The three faces of Latinity: signifier, repetition \\ and repression
}

\author{
Keylla Barbosa \\ Psicóloga, especialista em \\ Saúde Mental e Coletiva \\ pela Unicamp, mestre em \\ Linguística pela Unicamp e \\ doutoranda em Psicanálise e \\ Psicopatologia pela Université \\ Paris Diderot-Paris VII. \\ keyllafb@yahoo.com.br \\ https://orcid.org/0000-0003- \\ $\underline{1710-5522}$
}

Recebido em:05/09/2020

Aceito em:29/06/2021

\section{Resumo}

Historicamente, a palavra "latino" marca de maneira diferente três povos distintos: os romanos, os europeus e os americanos. Tomando como ponto de partida essa recorrente nomeação, este artigo visa discutir, a partir do ponto de vista do significante "latino" seus significados e seus efeitos em cada um desses três cortes temporais. Afim de nos aprofundarmos nisso que insiste na repetição não necessária, mas contingente, deste significante, usaremos do método psicanalítico com o objetivo de articular insistência, repetição e recalque. Deste modo, poderemos abarcar isso que, da insistência do significante latino, no plano da nomeação, por mais de 2.500 anos de história, não pode ser dito e por isso, pela via da repetição, não cessa de se inscrever.

Palavras-chave: latino, latinidade, significante, repetição, recalque

\section{Abstract}

Historically, the word "Latin" marks three different peoples: the Romans, the Europeans and the Americans. Taking this recurring nomination as a starting point, this article aims to discuss, from the point of view of the "Latin" signifier, its meanings and its effects in each of these three temporal cuts. In view of delve deeper into that which insists on the unnecessary but contingent repetition of this signifier, we will use the psychoanalytic method in order to articulate insistence, repetition and repression. In this way, we will be able to embrace what, from the insistence of the Latin signifier, as nomination, in more than 2,500 years of history, cannot be said and therefore, through repetition, it does not cease to inscribed itself.

Key words: latin, latinity, significant, repetition, repression 


\section{Introdução}

Este artigo se pretende um território de elaboração e circulação de ideias, onde hipóteses serão lançadas através da análise de noções, de termos e de conceitos contingentes que, desta maneira, dependem então de suas histórias e de seu tempo, assim como dependem também da história e do tempo de quem os escreve. Este artigo é um ensaio de ideias concebidas além-mar, mas que seguramente começaram a ser concebidas muito antes, ainda em terras tupiniquins, ou o que chamo de meu território, o Brasil.

Considerando que eu sou uma brasileira que no atual momento está vivendo na Europa para fins de estudos, eu poderia propor aqui uma discussão sobre o que é ser uma brasileira no exterior ou sobre o que é ser uma latino-americana na Europa, ou seja, eu poderia falar dos entraves, dos preconceitos, das fantasias, dos juízos de valor, do imaginário, etc., que circundam a vida de quem deixou um país como o Brasil para viver em um outro como a França, mas, na verdade, eu gostaria de propor aqui uma generalização - já que, generalizações não são necessariamente ruins podendo ser inclusive muito úteis de um ponto de vista coletivo. Deste modo, a minha pergunta aqui não será: o que é ser uma latino-americana - dentro ou fora de seu território de origem - mas sim, deslizando em uma diacronia em direção ao passado, a pergunta que quero colocar neste artigo é: o que é ser uma latina? O que é ser um latino?

Proponho aqui, então, uma discussão a respeito da noção de "latino". Uma palavra conhecida de todos, mas talvez ainda insuficientemente explorada em seus significados possíveis e em seus potenciais - sejam eles criadores ou destruidores. O que é ser latino? Quem são os latinos? Como é ser latino? Para que essas questões e para que esse significante caísse sobre mim não como algo que me define, mas sim como algo que me interroga, foi preciso que eu me distanciasse do meu território de origem estendido, ou seja, a América Latina.

Tentar uma primeira resposta parece simples: atualmente, os latinos são aqueles que nascem na América Latina. Mas então cabe uma outra pergunta: por que a América nasceu latina? Ou seja, por que essa palavra entre todas as outras existentes foi a escolhida para nomear uma parte do tal "novo mundo" - que de novo só tem o nome? Todas essas perguntas nos fazem voltar mais de dois mil anos na história para responder: os latinos, na verdade, são os romanos, aquele povo imperialista que dominou uma parte da atual Europa. Europa esta que fala, então, línguas derivadas do latim, Europa esta que, em parte, cruzou o oceano em direção ao oeste, invadiu um território por eles desconhecido e impôs suas línguas latinas.

Bom, neste caso, encontramos uma outra resposta simples. A América Latina leva esse nome pois é a parte da América que, devido a colonização, fala línguas latinas, em oposição a uma suposta América Anglo-saxônica. Será suficiente? No escopo deste artigo, a resposta é não. Se fosse o caso, por que então a América Latina não foi chamada de América Ibérica, Iberoamérca, América Lusoespânica ou qualquer outro nome derivado de suas antigas metrópoles? Ou então, se o que estava em jogo era uma questão de origem linguística, podemos nos perguntar ainda, por que ela não foi chamada pelos nomes dos povos que nela habitavam antes da colonização, povos que em grande parte a constituiu e que nela habitam até o presente momento? Isso é, por exemplo, o que sugere Lélia Gonzales ao propor que seria politicamente mais democrático, culturalmente realista e logicamente coerente que a América Latina se chamasse Améfrica Ladina (GONZALES, 1988).

O engodo da resposta que atribui às línguas latinas o nome da América começa pelo simples fato numérico de que cinco são as línguas latinas (português, espanhol, francês, italiano e romeno) e na América se fala, do latim, apenas duas, o português e espanhol, com exceção da Guiana Francesa que fala francês (e faz parte do território francês além-mar). Além disso, o conceito de América enquanto território latino apresenta outras imprecisões. Temos por exemplo, o Canadá onde se fala francês e inglês, mas que, embora esteja na América, não entra na subdivisão latina; temos ainda Belize, Guiana e Jamaica que têm o inglês como língua oficial, o Suriname que tendo sido colonizado pelos holandeses, guarda esta língua e Porto Rico que é um estado livre associado aos EUA tendo como línguas oficiais o espanhol e o inglês. Além da diversidade das línguas derivadas dos conquistadores, é preciso levar em conta também todas as línguas nativas que são, ainda hoje, em maior ou menor medida faladas na América, bem como as migrações tardias de outros povos, como por exemplo os japoneses, chineses, poloneses, alemães entre outros. É importante ressaltar 
que essa unidade virtual que leva o nome de seus conquistadores não forma um todo nem geográfico, nem político-econômico e menos ainda cultural. Neste caso, cabe a pergunta: o que teria em comum esses povos que justificaria a existência, para eles, de um denominador comum? E por que entre tantas possibilidades de nomes foi a palavra latina que permaneceu?

Esta é então a grande questão que vai guiar as articulações propostas neste artigo. Nas próximas páginas, irei tratar a noção de latino/a como um significante e assim tentar esboçar um mapa da sua errância nas histórias de seus povos. Usarei aqui a noção de significante como foi empregada primeiro pelo linguista Ferdinand de Saussure (1916/1977) e depois pelo psicanalista Jacques Lacan. Para este último, o significante é o sinal de uma ausência. Ele se coloca no lugar de algo que não se apresenta, é, portanto, um sinal que faz menção a uma falta. Em si, o significante não significa nada e quanto mais ele não significa nada, mais indestrutível ele se torna. Ele é "o instrumento com o qual se exprime o significado desaparecido" (LACAN, 1955-1956/2010, p. 158), assim, não há significados rígidos, fixos ou imutáveis, e isso é fundamental para o desenvolvimento das hipóteses deste artigo. Um significante não é seu significado, assim como um significado não é a coisa em si, o objeto. Um significante está sempre se relacionando com outro formando uma cadeia, e essa articulação em cadeia tem como resultado os significados, portanto, é da relação de um significante com outro que surge o significado. O cerne da questão é que, para este autor, o significante sendo aquilo que traça a história através de suas marcas, ele determina o sujeito. "Se o que Freud descobriu, e redescobre com um gume cada vez mais afiado, tem algum sentido, é que o deslocamento do significante determina os sujeitos em seus atos, seu destino, suas recusas, suas cegueiras, seu sucesso e sua sorte" (LACAN, 1957/1998, p. 33-34).

Partindo da relação arbitrária entre significante e significado (SAUSSURE, 1916/1977) iremos aqui nos ater, de um lado, à parte do signo que se transmite enquanto materialidade sonora - o significante latino - e, de outro, às possibilidades que esse significante encontrou de se unir a diferentes significados ao longo da história de sua existência. Tomarmos ambos, significante e significado, como elementos de processos psíquicos tais como a negação (recalque, foraclusão ou denegação), a identificação, o sintoma, a sublimação etc.

Partindo dos diferentes modos de negação, apresentados por Freud e restabelecidos por Lacan, no escopo deste trabalho, um dentre esses recursos nos será mais caro: o recalque e o retorno do recalcado.

No interior da teoria psicanalítica, o recalque/repressão - ambas traduções da palavra alemã Verdrängung - é uma das noções mais importantes, segundo Freud: "A teoria da repressão é o pilar em que repousa o edifício da psicanálise" (1914/2012, p. 186). Presente desde seus primeiros estudos e artigos, ela foi pouco a pouco trabalhada por Freud até que em 1915, ele dedica a este tema um de seus escritos metapsicológicos ${ }^{1}$, que é então chamado "O recalque" (2004), texto incontornável na abordagem desta questão.

Grosso modo, o recalque é um dos destinos possíveis de uma pulsão - ou seja, de um estímulo interno -, que encontrou resistências a sua satisfação. Se o estímulo fosse externo, nos diz Freud, o mais eficaz seria fugirmos, porém "o Eu não pode fugir de si mesmo" (1915/2004, p. 177). Dizendo de outro modo, uma pulsão que não pode, por algum motivo, alcançar sua meta, que é a satisfação, pode então sofrer recalcamento. Neste caso, o recalque pode agir no sentido de assegurar a instabilidade causada no aparelho psíquico por uma pulsão que não pode - pelas mais diversas razões subjetivas ou objetivas - encontrar satisfação. Assim, a condição para que haja recalque se repousa sobre as forças de prazer e desprazer, de modo que o desprazer causado pela pulsão seja maior que o prazer que a satisfação dessa pulsão poderia trazer. O grande ponto desta questão é que, a ocorrência do recalque não impede que o representante da pulsão continue a existir no inconsciente. Uma vez que ele é expelido da consciência, mas não destruído, tendo sua existência inconsciente assegurada, ele vai tentar voltar para a consciência em busca de satisfação para a pulsão à qual ele se liga.

1 Freud define esta última pela primeira vez no artigo O inconsciente (1915/2010). A metapsicologia constitui a superestrutura teórica da psicanálise e constrói uma identidade epistêmica pare esse saber. A metapsicologia aborda a psicanálise em três níveis de compreensão: econômico, dinâmico e tópico. O nível econômico se atém as quantidades de excitação que compõem o aparelho psíquico; o nível dinâmico se refere as forças que investem nas representações psíquicas e as forças contrárias, ou seja, as da resistência e de defesas psíquicas; por fim o nível tópico se relaciona com a topografia do aparelho psíquico que é composto por sistemas. 
Este retorno do recalcado é o que dentro da psicanálise, convém chamarmos de sintoma. O afeto que investe a representação recalcada, uma vez que a satisfação primeira foi impedida e que a barreira da repressão está continuamente ativa tenta, por vias indiretas, encontrar uma satisfação substitutiva através de distorções de seu conteúdo. Essas distorções, ou seja, os sintomas, são ao mesmo tempo, para o sujeito, fonte de infortúnio e satisfação, ou seja, portam uma "ambiguidade engenhosamente escolhida" (FREUD, 1916-1917b/2014, p. 389). Já segundo Lacan, a partir da introdução na psicanálise da nação saussuriana de significante o sintoma passa a ser "o significante de um significado recalcado da consciência do sujeito" (Lacan 1953/1998, p. 282), ou seja, se há um significado recalcado, haverá sem dúvidas, a repetição sintomática de um significante; tese que será, então, fundamental para a discussão proposta neste artigo.

Além da tese de que a repetição de um significante pode trazer a marca de um recalcado, partiremos também da hipótese freudiana do determinismo psíquico (FREUD, 1916-1917a/2014), ou seja, de que aquilo que é inconsciente é decisivo e indefectível. Dito de outro modo, um sujeito, um grupo ou um povo é determinado por aquilo que nele há de mais escondido e desconhecido. Neste caso, o que este artigo pretende analisar é o que este significante - latino/latina - oculta e também como que isto que está oculto pode provocar ações e reações que influenciaram o curso da história das gerações e gerações de povos dominados e colonizados sob este mesmo significante. Para isso, este artigo vai examinar três momentos históricos diferentes nos quais este significante cumpriu um papel determinante em função de sua presença e portanto, em função das relações de força que ele produziu e produz a partir de algumas narrativas. Evidentemente, minhas intenções não almejam fazer uma análise histórica dos desdobramentos da latinidade para os povos assim chamados, nem tampouco pretendem esgotar a análise dos significados desta palavra ao longo de sua história. Minha proposta é, a partir de alguns pontos, dar início a uma discussão a respeito dos efeitos deste significante enquanto um ator na formação de seus povos, enquanto algo que os nomeia. Para tal finalidade, foi necessário um triplo recorte, a partir da suposição da existência de três grandes momentos nos quais o nome latino marcou, de modos distintos, sua presença, a saber, os latinos romanos, os latinos europeus e os latinos-americanos.

\section{Os primeiros latinos}

Podemos dizer que os primeiros latinos foram os habitantes do Latium, uma região da Itália central às margens do mar Tirreno no Mediterrâneo. Essa rica região em termos de natureza e geografia viu surgir e desaparecer muitas civilizações ao longo de sua história, sendo a romana a mais importante entre elas. Atualmente, o Latium ainda é uma região economicamente muito ativa, sendo de tal modo, a área mais populosa da Itália (HACQUARD et al., 2010).

A origem do povo latino é ainda cercada de mistérios, mitos e lendas. Mesmo as pesquisas documentais mais sérias não conseguem traçar com precisão os acontecimentos que desembocaram no nascimento de uma nova civilização a partir dos povos que habitavam e circulavam nessa região, entre eles, italiotas, etruscos e gregos. Porém, em termos gerais, uma data é aceita pelos historiadores como sendo a fundação legendária de Roma: 753 AC. (HACQUARD et al., 2010).

Quando se fala em nascimento de Roma, logo lembramos daqueles dois irmãos que abandonados ainda bebês foram encontrados e amamentados por uma loba. A história de Rômulo e Remo compõem um dos mais importantes mitos sobre a origem do povo romano. Mais uma vez, encontramos nessa história traços do mito do herói: pessoa de origem nobre que é abandonada à própria sorte para que não cumpra seu destino, mesmo se, o próprio ato de tentativa de interrupção de um destino é aquilo que em si mesmo o traça.

O fato é que, a famosa disputa de poder entre os irmãos que culmina na morte de um pelo outro, ou seja, o assassinato que dá origem ao povo latino enquanto tal, não é, certamente, o único evento marcante na origem deste povo. Antes mesmo de Rômulo e Remo, muitos outros acordos, guerras e intrigas traçaram a origem e, certamente, traçaram as características desse povo. Obviamente seria impossível nos referirmos 
aqui a todos esses numerosas e interessantes episódios narrados nas obras de Virgílio (70 a.C. - 19 a.C.) e Ovídio (43 a.C. - 18 d.C.), entretanto, como nosso objetivo neste trabalho é focar nos caminhos traçados pelo significante, é, então, fundamental citarmos a história legendária de um dos reis que governou sobre o Latium, o rei Latinus, este sim, o primeiro de seu nome.

A região do Latium foi a terra escolhida pelo Deus Saturno ${ }^{2}$ para ser seu novo lar quando, expulso do trono por seu filho Júpiter, foi obrigado a se refugiar. Ele lá habitou e lá criou uma nova família. Saturnia tellus, a terra de Saturno, como disse Virgílio em Geórgicas (1982). Entre os descendentes de Saturno está o então rei Latinus. Ele receberá, um dia, a visita de Eneias, filho de Vênus, que tendo partido de Tróia, após perder a guerra, está à procura de uma nova pátria. Pleno de admiração pelo jovem herói guerreiro, ele o oferece sua filha Lavinia em casamento. Após a morte de Latinus, Eneias o sucederá e dará a seu povo o nome de latino (HACQUARD et al., 2010). E assim, nomeados como tais, nascem, os primeiros latinos sobre a terra.

Rômulo e Remo virão, então, no interior desta mesma linha de sucessão real, algumas gerações mais tarde. Eles são filhos do deus Marte e de Rhéa Silvia, herdeira oficial do trono de Latinus, trono este que lhe foi roubado pelo seu tio. Os gêmeos são então abandonados a própria sorte pelo tio e no rio Tibre, e após o encontro com a loba que os alimentou eles foram criados pelo camponês, Faustulus, e sua esposa, Larentia. Adultos e conhecedores de seu destino e de sua origem, os irmãos vão em busca do reino que lhes pertencia (HACQUARD et al., 2010). Após algumas desavenças entre os irmãos que são contadas de maneiras distintas por vários dos escritores da história do povo romano, Rômulo assassina seu irmão Remo e é então que de uma morte nasce a vila que virá a ser a mais importante do mundo latino: Roma.

Segundo a versão mais cética do historiador Tito Lívio (59 a.C. - 17 d.C) foi o direito de nomear a cidade e de assim poder governá-la que motiva o fratricídio. Romulo avança e nomeia a cidade a partir de seu próprio nome (1955). Roma, a cidade de Rômulo, filho de marte, filho da guerra.

É importante aqui ressaltar que toda essa história chegou até nós através dos versos da Eneida de Virgílio (2014) e das Metamorfoses de Ovídio (2017) que foram escritos provavelmente no século 1 a.C., ou seja, muito tempo depois da suposta temporalidade desses acontecimentos. Neste momento Roma já não era mais nem um reino, nem uma república, ela já era um império comandado por Augusto e este, assim como Júlio César seu antecessor, pertenciam a família Julii conhecidos por serem descendentes diretos da Deusa Vênus. Esta foi provavelmente escolhida como mãe protetora dos Julii por ser a mãe de Eneias, personagem que não apenas compõe o fundamento do povo romano, tendo sido o sucessor do rei Latinus, como também é tido por eles como um dos maiores guerreiros que já existiu (HACQUARD et al., 2010). Neste caso, fica a questão sobre as possíveis sutilezas políticas presentes na obra de Virgílio ao remeter a origem do povo romano a deusa Vênus. Deste modo, propositadamente ou não, esta obra, uma vez que escrita sobre o domínio do Imperador Augusto também descendente desta linhagem, assegura tanto a legitimidade de Augusto no poder - em termos sucessórios - quanto o inevitável de um destino de guerras, conquistas e vitórias sob a égide da deusa.

Além da deusa Vênus por parte de seu filho Eneias, nas versões históricas e mitológicas aqui citadas, os latinos também são descendentes, mesmo que distantes, de Saturno, ancestral da família de Latinus e posteriormente de Marte - pai de Rômulo e Remo e portanto pai simbólico deste povo. No mundo latino Vênus é a deusa da beleza, do amor, dos prazeres do amor, da sedução e da fecundidade. Mãe dos guerreiros, é ela que lhes dá a vitória; Saturno, deus do tempo, muito mais doce que o Saturno grego, chamado de Cronos, é venerado principalmente no mês de dezembro, período anterior ao solstício de inverno no hemisfério norte. Este período, conhecido como Saturnalias (GRIMAL, 2003), era o momento de uma grande festa onde se celebrava o fim de um ciclo e o começo de um outro, ou seja, o deus do tempo prepara a renovação do mundo para um retorno ao seu estado original. É o tempo que marca o fim e o começo, momento de preparação da

2 No escopo deste artigo, as divindades do mundo greco-romano, que são em grande parte as mesmas -posto que os romanos absorveram muito a cultura e a religião grega - serão citadas pelos seus nomes latinos. Embora os nomes gregos tenham se popularizado muito mais, como aqui nosso interesse é traçar algumas vias da história do povo latino, usaremos apenas os nomes oriundos desta língua, a fim de guardar as sutilezas nas diferentes concepções de cada deus ou deusa por cada um dos dois povos. 
terra para iniciar o plantio de acordo com as estações. Marte, por sua vez, é o deus da guerra, da carnificina, mas é também o protetor da agricultura, do plantio, da colheita e da vegetação. Essa mistura de características veio provavelmente da combinação entre antigos deuses latinos e gregos. É interessante lembrar que, segundo Ovídio em Metamorfoses (2017), Marte foi amante de Vênus, que era casada com Vulcano e com ela teve um filho, o Cupido e uma filha, a Harmonia.

Se esses foram de certo modo os deuses escolhidos como pater e mater do povo latino, é importante notar que não necessariamente eles eram os mais cultuados cotidianamente. Os latinos tinham a família como uma das instituições mais importantes e respeitadas, assim sendo, os deuses do lar eram enormemente cultuados, inclusive Lar é seu nome. Lar familiaris é a divindade cultuada dentro da casa onde é constantemente ornada por flores, além disso, ao pater familias cabe lhe oferecer sacrifícios nas datas importantes a fim de garantir a proteção de sua casa e família (GRIMAL, 1981).

Para os latinos, a religião era importantíssima na vida cotidiana. Eles tinham, assim, uma infinidade de deuses aos quais podiam se endereçar em função de uma atividade ou de uma situação específica. Esta infinidade de deuses vem do fato de que os romanos, desde as primeiras guerras e conquistas assimilavam naturalmente os deuses e os ritos dos povos conquistados. Deste modo, a vida romana era repleta de rituais, oferendas, cultos. Assim como a família de Júlio César e de Augusto se pretendiam descendentes da deusa Vênus, as famílias dos patrícios também se pretendiam descendentes de algum ancestral mais ou menos divinizado. Na maioria dos casos, os ancestrais das famílias eram reconhecidos em deuses homens, ou seja, a figura mais importante da família, o pater familias era herdeiro de um deus que seria então o pater máximo desta (HACQUARD et al., 2010).

Outro ponto importante a ser destacado é que os latinos eram em geral camponeses. Mesmo que Roma tenha sido a maior cidade do mundo antigo, a maior parte da população sob o domínio de Império Romano vivia no campo e levavam uma vida bem simples, onde a praticidade, a perseverança e a paixão pela terra eram os valores mais presentes. A casa dos romanos era também muito simples e eles só tinham como mobília ou como vestimentas, o necessário, pois, grosso modo, os bens materiais não era algo que lhes interessava muito.

Também é importante frisar que os romanos eram, em grande parte, soldados treinados para a guerra. A inclinação pelas conquistas e pela expansão do território veio pouco a pouco à medida em que eles se viram cercados por outros povos que poderiam ou não ameaçar a instabilidade de seu reinado, os latinos foram se expandindo e acoplando os povos vizinhos. A sede por poder e território aumenta com a passagem da monarquia à república e evidentemente se estabelece como a meta principal durante o período do Império (HACQUARD et al., 2010).

A população civil, durante o período do império, trabalhava menos do que durante a república. Grosso modo, habituada à política do pão e circo, e apoiada sob o modo de vida simples que sempre levaram, a população se contenta em comer e se divertir. O lado festivo e alegre desse povo sempre foi uma de suas características mais marcantes, ou, ao menos, podemos dizer que essa foi a característica que mais fez história. Ainda hoje os latinos são reconhecidos pela sua alegria, pelas suas festas, e por serem calorosos e receptivos; o que obviamente faz fronteira semântica com a bagunça, a desordem, a sujeira e o caos. Grandes e abundantes festas e orgias é a causa, por exemplo, do seguinte comentário de Sêneca (4 a.C. - 65 d. C.), um dos principais filósofos e dramaturgos da história romana, que por volta do século IV a.C. escreve em Consolação a minha mãe Helvia: "os romanos comiam para vomitar e vomitavam para comer" (2005).

Aos poucos, dada a enorme desigualdade social entre patrícios e plebeus, o apetite pela guerra e pela conquista, acaba por dar início, por volta do século III d.C., a uma instabilidade social generalizada onde a população passa a ter até mesmo dificuldades para comer devido à alta dos preços e a escassez de alimentos (HACQUARD et al., 2010). Este é apenas o início de um longo processo de crise deste império que desembocará em sua divisão e em uma lenta perda de poder de ambas as partes que verá em breve o fim de sua hegemonia. 


\section{Os segundos latinos ou a expansão latina na Europa}

Como todos sabemos, o Império Romano, invadiu e dominou uma grande parte da Europa. Para que essa expansão territorial e cultural fosse possível, muitas guerras foram feitas e muitos povos foram massacrados ao mesmo tempo em que parte dessas culturas era absorvida. O Império Romano foi então formado por muitos povos distintos. Uma pluralidade de modos de vida e de línguas que quando não eram absorvidas acabavam desaparecendo em função dos costumes romanos e do latim.

Com a queda do Império Romano e sua divisão em dois - o Império do Oriente e o Império do Ocidente - pouco a pouco, aquela que teria sido a maior potência mediterrânea perde suas forças e acaba por volta de 476 d.C. quando Rômulo César renuncia ao seu posto de imperador no império romano do ocidente (HACQUARD et al., 2010). As ditas invasões bárbaras que marcaram este período preservaram em partes os modos de vida e a organização romana, por isso as línguas faladas hoje no chamado velho mundo derivam do latim mesmo que ele tenha mudado em função das línguas faladas pelos povos ditos bárbaros que eram em grande parte celtas.

Muita história se passou desde o fim o Império Romano até a formação dos estados atuais europeus. Obviamente, não cabe aqui entrar nos detalhes destes acontecimentos. Porém, as guerras territoriais e as disputas por poder continuaram seu curso ao longo de toda a Idade Média e não apenas. É fundamental lembrarmos que ainda no século passado a Europa causou e passou por duas grandes guerras devido a questões territoriais, políticas e econômicas, ou seja, hoje, o território europeu comemora uma anistia rara de mais de 70 anos.

A América Latina, a partir do momento em que é assim batizada se torna o fruto de uma segunda dominação pelos povos latinos, uma segunda onda imperialista que desta vez cruza o oceano atlântico. Das duas ondas latinas, apenas uma delas foi nomeadas enquanto tal. Nesse sentido, cabe a pergunta: por que a parte da Europa que compôs o Império Romano e que portanto fala línguas latinas, assim como parte dos americanos, não foi chamada Europa Latina? Por que em nenhum momento da história, os países europeus de línguas latinas não se uniram politicamente, economicamente ou mesmo culturalmente para fins em comum? Ou seja, por que na Europa, não se criou nenhum tipo de unidade sociopolítica em torno desta origem em comum? E por que, por fim, essa suposta unidade linguístico cultural no nível do nome veio a aparecer sob a América após o fim do período colonial? Quer dizer, em momento algum durante a formação dos estados europeus que tinham feito parte do território romano houve um reconhecimento dessa origem comum a ponto de fazer desta origem um nome. A Europa Latina nunca existiu enquanto uma nomeação. Itália, França, Romênia, Espanha e Portugal compartilham entre si o fato de que são países de cultura e línguas vindas do povo latino, mas nem por isso se chama Europa Latina, enquanto que, posteriormente o olhar imperialista sobre a América criará uma grande, e aparentemente semelhante, massa latina que assim será denominada.

Neste sentido é interessante notar que, apesar de haver um reconhecimento claro de sua origem latina, essa parte da Europa carrega também - assim como a América - traços de muitos outros povos em sua constituição. Porém, por algum motivo, foi o significante latino que se propagou e que fez história - de dominação - do outro lado do oceano Atlântico. Na própria história da Europa que aqui chamaremos de Europa Latina, houve então uma sorte de identificação com o seu dominador primevo, o que em termos simbólicos incute uma possibilidade de propagar e repetir essa história de conquistas sobre outros povos. Quando a formação de um povo se dá pela via da guerra, muitos traços identificatórios estão em jogo - traços do povo dominador e traços do povo dominado - essas identificações podem ser múltiplas e inclusive contraditórias e cada uma produzirá seus efeitos segundo suas possibilidades de atuação.

Tomando a França como exemplo, o reconhecimento da latinidade não impediu, por exemplo, a aparição de um outro pólo de identificação: os gauleses.

A Fim de traçar de forma muito resumida a história entre gauleses e romanos, irei tomar dela apenas o último ato. Entre 50 e 58 a.C. após várias batalhas, Júlio César vence e conquista o território e o povo gaulês (CÉSAR, 1993). A vitória de Júlio César sob o líder gaulês Vercingétorix, batalha que se passou no território 
que hoje compõe a Borgonha francesa, não por acaso é um dos fatos da história da França que mais encanta. Esse evento deu origem a história em quadrinhos Asterix que em suas narrativas, inverte o ponto de vista e mostra as batalhas a partir dos gauleses que são então tomados como um povo que resistiu às intenções daquele que acabou sendo de fato seu dominador. O sucesso de Astérix na França e no mundo é apenas um exemplo das complexas relações que se estabelecem na ocasião de uma disputa por poder. Entre conquistador e conquistado, no plano das identificações, a posteriori, podemos dizer que entre os polos opostos de um jogo de forças não há anulação. No inconsciente dos povos, eles podem ser o que quiserem, romanos e gauleses, mesmo que a guerra tenha tido um só vencedor e um só perdedor. A não contradição é uma das principais características do inconsciente, segundo Freud:

O âmago do Inconsciente consiste de representantes instintuais que querem descarregar seu investimento, de impulsos de desejo, portanto. Esses impulsos instintuais são coordenados entre si, coexistem sem influência mútua, não contradizem uns aos outros (...).

Nesse sistema não há negação, não há dúvida nem graus de certeza (FREUD, 1915/2010, p. 93).

Neste sentido podemos pensar que a transformação dos gauleses em resistentes e não em perdedores ou conquistados, viria no sentido de uma formação de compromisso que permite essa dupla atribuição de origem. Uma vez este último transformado em resistente, não há qualquer impossibilidade de que essas duas representações convivam de modo consciente sem contradição, enquanto inconscientemente, perdedores, vencedores ou resistentes, se estabelecem como representações distintas, até mesmo opostas, mas, de modo algum, excludentes.

Avançando um pouco mais na história, após as grandes navegações e a colonização da América em sua maioria pela vertente dominante latina, nos vemos envoltos a este significante que aqui representa o conquistador. Diferente da expansão do Império Romano na Europa, a colonização da América não se deu através de uma guerra anunciada na qual existe um código ou mesmo uma ética a ser seguida, na qual ambos os lados têm condições semelhantes de lutar, de avançar ou de defender seus territórios, seus ideais ou sua cultura. A colonização da América se deu em uma indistinção entre civis e militares e buscava o extermínio de povos que, após obterem o estatuto de humanos, foram considerados inferiores. A América que aos poucos é latinizada, não carrega desde o início esse nome. É quando ela passa a se tornar independente que a referência ao dominador aparece, e neste momento, essa referência remete, então, a duas gerações anteriores, estabelecendo, assim, um laço entre três gerações no qual somente a duas delas esse significante foi atribuído.

Uma das mais antigas referências à América enquanto latina, está na obra de Michel Chevalier (18061879) chamada Lettres sur l'Amérique du Nord (Cartas sobre a América do Norte) ${ }^{3}$ e publicada em 1836. Nesta obra, é interessante notar, o autor traça uma divisão semelhante na Europa e na América, ambas são formadas por dois - e apenas dois - grandes povos: os germânicos e os romanos. Assim, no território europeu teríamos a Europa latina e a Europa teutônica e, no "novo mundo", "A América do Sul é, como a Europa meridional, católica e latina, enquanto a América do Norte pertence a uma população protestante e anglo-saxônica" (CHEVALIER, 1836, p. XI) ${ }^{4}$. Isso já se inscreve no contexto de uma rivalidade entre o mundo dito latino e o mundo dito anglo-saxônico, banhada por uma disputa de poder que neste momento começa a ser ameaçada também pela "raça eslava, que apareceu recentemente" (CHEVALIER, 1836, p. XI) existissem antes de serem conhecidos mais de perto pelos latinos do século XIX.

Aqui, o que está em jogo no terreno europeu e que é imputado aos americanos, por uma certa ação lógica, é a questão sobre uma suposta superioridade racial. Assim, na América, só se via o reflexo de um

3 Obra não traduzida para o português.

4 Tradução minha. No original: "L'Amérique du Sud est, comme l'Europe méridionale, catholique et latine. L’Amérique du Nord appartient a une population protestante e anglo-saxonne ». No corpo do texto, a partir desta citação, as traduções de obras não traduzidas para o português serão minhas.

5 Tradução minha. No original : "race slave, qui est récemment apparue". 
mundo latino ou anglo-saxônico, orgulhoso de suas conquistas. Não havia lugar para a existência de uma representação ou de um significante que fizesse referência aos povos indígenas ou africanos que também compõem uma grande parte dessa mesma América.

\section{Os terceiros latinos ou a colonização da América}

Como aqui o que me interessa é seguir o significante, farei uma breve história do nome América Latina, a começar, então pelo primeiro significante deste nome: América.

De um modo geral todos sabem que o nome América vem de Américo Vespúcio, ou Amerigo Vespucci, um italiano que, a serviço do governo da Espanha, tendo participado anteriormente das viagens com Cristóvão Colombo, assume uma nova expedição que cruzaria o Atlântico, resultado: as Índias de Colombo se tornam, o "novo mundo" de Américo. Assim, o nome América aparece em 1507 com a publicação de Introdução a Cosmografia do geógrafo alemão Martin Waldseemüller (FARRET; PINTO, 2011). Neste livro, o autor apresenta um mapa do "novo mundo" no qual ele é chamado pela primeira vez de América, em clara homenagem a Américo Vespúcio. É importante ressaltar que embora o nome América existisse desde o século XVI, a noção de pertencimento, ou seja, uma identidade americana parece surgir com mais força através dos processos de independência de seus países (BRANDALISE, 2013), ou seja, no fim do século XVIII e início do século XIX, como uma forma de defesa contra possíveis revanches de suas antigas metrópoles.

Mas voltemos à questão. Quando é que uma parte da América passa a ser designada como latina? Qual o contexto de seu segundo batismo? Sobre este ponto encontramos o extenso debate de alguns autores que tentaram traçar a história desse nome. Participaram dessa discussão, John Leddy Phelan (1993), Arturo Ardão (1980) e Miguel Rojas Mix (1991), entre outros. A partir desses e de outros autores, em seguida, vamos citar os pontos de ancoragem mais importantes da história da fixação deste significante enquanto nome. Para quem está familiarizado com este debate, aqui, não seguiremos a cronologia das hipóteses de origem do nome América Latina, mas sim, a cronologia das fontes onde este nome foi, pelas primeiras vezes, esboçado.

Comecemos pelas publicações de José Maria Torres Caicedo (1830-1889) pensador e jornalista colombiano e de Francisco Bilbao (1823-1865) pensador chileno. Ambos residentes em Paris em meados de 1850, trazem sob suas penas a expressão "América latina". Precisamente em setembro de 1856, Caicedo publica um poema chamado "As duas Américas" onde se lê a frase: "A raça da América latina" (CAICEDO 1856/1857) ${ }^{6}$. Nota-se que o termo "latina" aqui aparece com letra minúscula posto que neste momento ele não se refere ao nome da América, mas a uma de suas características. Entretanto em junho de 1856 - ou seja, três meses antes de Caicedo publicar seu poema - Bilbao teria cunhado este termo durante uma conferência em Paris, na qual descreveu essa referida parte da América como "Latina, saxônica e indígena", afirmando ainda a importância de "perpetuar nossa raça americana e latina"” (BILBAO, 1856). É notável que o surgimento da ideia de uma América "latina" é correlata a noção de raça, que, ao longo do século XIX, compõe um dos pilares do pensamento intelectual e "científico" europeu. Se raça existe e se existem povos latinos, a pressuposição de uma "raça latina" pode surgir e se estabelecer no campo das ideias sem provocar nenhuma contradição ou estranhamento.

No que concerne à reflexão sobre a primeira vez em que o termo "latina" foi empregado como característica da América, não cabe aqui entrar no debate sobre quem teria expedido a carteira de identidade de América Latina, até porque, até este momento, ela ainda não tinha sido oficialmente nomeada, posto que a passagem do adjetivo para substantivo só veio a se efetivar mais tarde de um modo tão difuso que não se pode atribuí-lo a uma personagem em específico. Entretanto, é de fundamental importância notar que este significante ainda produz seus efeitos na história de seus povos que desde o século 1 a.C. não cessam de se inscrever.

6 No original: "Las dos Américas" e "La raza de la América latina”.

7 No original: "latina, sajona e indígena" e "tenemos que perpetuar nuestra raza Americana y Latina”. 
Ainda neste mesmo período - em que a França vivia o contexto do expansionismo territorial de Napoleão III - encontramos a Revista das Raças Latinas ${ }^{8}$, publicação que circulou entre 1859 a 1864 e que tinha como pano de fundo a exaltação do que eles então chamavam de "raça latina" em detrimento de outras menos potentes ou importantes. L.M. Tisserand em 1861, publica nesta revista um artigo chamado "Situação da latinidade" onde aparece a expressão América latina, mas usando a palavra latina ainda como adjetivo. Neste e em outros artigos dessa mesma revista, é flagrante a ideia de que a América sendo também um continente povoado pelos latinos merece ser resgatada e elevada em seu status, pois o que estava em jogo era a suposta superioridade deste povo. Hoje sabemos os efeitos que essa ideia de salvação ou resgate de um povo dito inferior por um povo dito superior teve nas mãos de Napoleão III. A seguir um breve extrato do tipo de pensamento propagado pela Revista das Raças Latinas e de qual era em geral a relação desses intelectuais com os, assim chamados, Americanos do Sul.

Publicando sucessivamente a biografia de todos os homens que ilustraram e elevaram a raça latina através de sua múltipla superioridade e genialidade a Revista faz um favor aos filhos e aos contemporâneos desses homens; ela prova que a espécie de desencorajamento que apoderou-se dos Latinos não tem nenhuma razão de ser e que eles sempre estiveram a altura de sua missão iniciadora.

Mas é acima de tudo, falando na Europa dos homens ilustres da América do Sul que a Revista é útil aos interesses que ela defende e assim ela cumpre um ato de alta justiça e de alta política. Durante muito tempo na Europa nós estivemos acostumados a acreditar que os latinos da América eram degenerados; atribui-se às guerras civis que destruíram as repúblicas hispano-americanas à um enfraquecimento desta raça, quando era uma exuberância de força e de vida que dever-se-ia ter-lhes atribuído. (F.R. 1859, p. 169) ${ }^{10}$.

Para que essa ideia, digamos, delirante de uma supremacia latina pudesse aparecer foi necessário foracluir, para usar o termo cunhado por Lacan (1955-1956/2010), a condição de miscigenada da América Latina. É na dimensão em que a foraclusão é a expulsão para fora do simbólico daquilo que não pode ser, por ele, representado que podemos dizer que todas as etnias indígenas que habitam a América e todas as etnias africanas que neste território foram escravizadas tiveram que ser negadas em prol da supremacia ilusória da latinidade. Ou seja, a supervalorização imaginária dos povos latinos, só se faz às custas da foraclusão da realidade da mistura cultural dos povos americanos e com um consequente apagamento dos signos dessas culturas. Aqui usamos o conceito de foraclusão e não o de recalque, pois, de um ponto de vista psicodinâmico, só podemos identificar o processo de negação em questão a partir de seus retornos. O retorno do recalcado se faz sempre pela via de um ciframento simbólico; o retorno do foracluido se faz pela imposição de um Real. O delírio é, para a psicanálise, o retorno no Real daquilo que foi expulso do simbólico (LACAN, 1955-1956/2010). Aqui, somamos aos motivos que levaram ao aparecimento, no século XIX, da ideia de uma supremacia latina a hipótese de que a existência, na América, de povos não-latinos foi foracluida e como retorno deste processo surge a ideia delirante de uma supremacia dos povos latinos.

Neste contexto, as ambições imperialistas de Napoleão III, em ressonância com essa ideologia, o levaram até o México através de uma dupla intenção: exercendo seu domínio sobre a América Latina, ele poderia, ao

8 Obra sem tradução para o português. No original: Revues des Races Latines.

9 No original: «Situation de la latinité ».

10 No original : «En publiant successivement la biographie de tous les hommes qui ont illustré la race latine et l'ont placée si haut par la multiple supériorité de leur génie la Revue rend un grand service aux fils et aux contemporains de ces hommes; elle leur prouve que l'espèce de découragement qui s'est emparé des Latins n'a aucune raison dêtre, et qu'ils sont toujours à la hauteur de leur mission initiatrice.

Mais c'est surtout en parlant à l'Europe des hommes illustres de l'Amérique du Sud que la Revue est utile aux intérêts qu'elle défend et qu'elle accomplit un acte de haute justice et de haute politique. Trop longtemps en Europe on s'est habitué À croire que les latins de l'Amérique sont complètement dégénérés ; on a attribué des guerres civiles qui déchirent les républiques hispano Américaines à un affaiblissement de la race qui s'y livre, quand cétait à une exubérance de force et de vie qu'il fallait les attribuer. ». O autor deste artigo assina apenas com suas iniciais, F.R., por isso não se sabe qual seu verdadeiro nome. 
mesmo tempo, expandir seu império e fazer barreira ao crescimento dos EUA enquanto potência mundial (DINIZ, 2007).

A aproximação francesa na América acaba por influenciar o pensamento intelectual da época que se volta em grande parte para este país. Talvez, o interesse pela intelectualidade francesa tenha sido uma maneira de se declarar independentes, ao menos no campo das ideias, de uma influência ibérica marcada pela colonização. A questão é que, ao mesmo tempo, este interesse, por parte dos atuais latino-americanos, e a receptividade francesa estavam marcados e tinham como pano de fundo as intenções expansionistas do Segundo Império. Entretanto, essa identificação com o mundo intelectual francês foi o começo do estabelecimento, na América, de um sentimento de latinidade, que surge talvez como uma tentativa de superar o trauma da violentíssima colonização. Tomando a identificação como nos apresentou Freud, ou seja, "como a mais antiga manifestação de uma ligação afetiva a uma outra pessoa" (FREUD, 1921/2011, p. 300) podemos afirmar que ela envolve, como tudo que é arcaico, uma boa dose de ambivalência instaurando ao mesmo tempo o amor e o ódio, a ternura e o desejo de eliminação de um objeto que tomado por ideal será colocado no lugar do Eu (FREUD, 1921/2011, p. 300). Este movimento só é possível a partir de um traço escolhido não ao acaso. Neste caso, o traço latino é o que pode se estabelecer de algum modo entre esses dois polos, posto que, os franceses não foram os atores mais importantes do nosso processo colonizador, mas ainda são latinos.

Isso quer dizer que nesta época, houve - e mesmo atualmente ainda há - uma considerável imigração de intelectuais da América hoje latina para a França, onde desenvolveram seus estudos e seus projetos de pesquisa. Deste movimento temos várias publicações que nos ajudam a traçar um pouco mais dos caminhos deste significante. Encontramos, por exemplo, a obra do Uruguaio Carlos Calvo (1824-1906) que em 1862 publicou na França o chamado Compêndio completo de tratados, convenções, capitulações, armistícios e outros atos diplomáticos de todos os estados da América latina compreendidos entre o Golfo do México e o Cabo Horn, desde os anos 1493 até os dias de hoje. Obra esta dedicada pelo autor ao Imperador Napoleão III. Aqui, a expressão América latina aparece muitas vezes, inclusive no título do livro, no título do primeiro capítulo, e ela aparece também na dedicatória reproduzida a seguir:

À sua majestade, o imperador Napoleão III. Senhor, sua majestade imperial e soberano da Europa, aquele que melhor compreendeu toda a importância da América latina e aquele que contribuiu da maneira mais direta ao imenso desenvolvimento do comércio entre a França e este vasto continente. Um filho das margens férteis do rio da Prata, contando com a benevolência habitual que é uma das características que distingue Vossa Majestade imperial, ousa vos solicitar, Vossa Majestade, que aceite a dedicatória desta obra (CALVO, 1862).

A partir deste momento surge, então, a noção de América latina; embora a passagem final da palavra "latina" de um adjetivo, que entre tantos outros caracteriza um povo, para o substantivo, que o nomeia e o insere numa certa cadeia de representações, só venha a se estabelecer um pouco mais tarde. A latinização da América tinha como objetivo, do lado europeu, um desejo da volta do sistema colonial com Napoleão III e do lado de uma parcela da elite intelectual na América a ideia de construir um "nós" com o mundo europeu que nos permitisse sair do atraso (FARRET; PINTO, 2011), mesmo que isso tivesse que ocorrer às custas da identificação com o dominador de outrora.

De um modo geral podemos dizer que o nome de América Latina conta a história das tentativas de apropriação deste território suficientemente vasto e variado para ser homogeneizado em um só nome cuja primeira parte faz referência à colonização europeia e a segunda ao imperialismo romano. Obviamente meu objetivo não é me opor à união cultural, política ou econômica dos países que fazem parte da América Latina, minha questão se coloca apenas sobre o fato de que o nome que funcionou foi exatamente este onde se encontram todas as nossas duas referências dominantes ao invés, por exemplo, de usarmos simples referências geográficas ou mais representativas. 


\section{Considerações finais}

Três gerações de latinos, mais de 2700 anos de história. Ao longo desses tantos anos podemos facilmente imaginar que uma imensa quantidade de significados foi atribuída ao significante latino/latina. O ponto é que não importa o quanto ele tenha mudado conceitualmente, ele continua não apenas existindo, mas instituindo, produzindo efeitos e nomeando povos. É então de fundamental importância dizer que, nessa longa jornada, esse significante marca sua presença acompanhado de ideais imperialistas. Como vimos, o imperialismo não está no ato fundador nem de Roma, nem do povo latino, mas, aos poucos esses dois significantes se associaram, e hoje, mesmo que essa relação seja de certo modo encoberta, com um pouco de pesquisa, ainda pode-se perceber o quanto eles estão associados.

Se ele permanece, por um tempo, sem muita força ativa - como por exemplo durante a Idade Média até a formação dos Estados Europeus - logo ele reaparece e se impõe como origem forçada a uma pluralidade de povos. Há algo do imperialismo romano que ainda não foi elaborado pelos seus descendentes. Há algo em torno deste significante que não pôde ser elaborado posto que ele não cessa de se inscrever há mais de 2.500 anos. E desse possível recalcado histórico que gira em torno do significante latino, nós só conhecemos os retornos, e todos sabemos, que, ao menos na América, esse retorno veio carregado de violência.

Longe de reduzir os objetivos imperialistas ou colonizadores apenas a uma dinâmica simbólica que envolve um significante, as intenções deste artigo giram em torno de levantar uma hipótese que parte, então, de um ponto de vista psicodinâmico e chamar atenção para algo não desprezível que é um nome, suas causas e seus efeitos. Uma nomeação nunca se dá ou não se dá ao acaso, e aqui, traçando um pouco as vias latinas, percebemos que, das três gerações de latinos, apenas duas foram nomeadas enquanto tal; tendo a Europa o reconhecimento da latinidade na sua origem, mas não no seu nome. É como se esse significante tivesse pulado uma geração para reaparecer, enquanto nome, em uma terceira, ou então, é como se, a fim de evitar o desprazer de uma representação conflituosa - que remete ao mesmo tempo ao dominador e ao salvador, àquele que conquistou, mas também àquele que está na origem - foi necessário um recalque que, como todo recalque, tem seus retornos, Neste caso, o retorno de recalcado do imperialismo romano sobre a Europa teria aparecido no nome latino dado à América, pois neste movimento, têm-se a impressão de apagar o traço de um povo dominado, guardando apenas a versão de um povo dominante. Mesmo se conscientemente, em geral, haja uma pressão para que se escolha um entre dois pares de opostos, ou seja, entre se reconhecer enquanto conquistador ou conquistado, enquanto certo ou errado, bom ou mau, violador ou violentado, inconscientemente, sabemos que a contradição não coloca nenhum problema e não implica nenhuma exclusão: o inconsciente é o antro da partilha entre amor e ódio, Eros e Tanatos. Nessa direção, pode-se pensar que o significante que nomeia a América de "Latina" pode ter sido o sintoma de um recalcado em torno do imperialismo romano sobre a Europa, o sintoma de uma impossibilidade em se colocar contra uma onda dominadora que não deixa muitas alternativas a não ser a identificação com o dominador, ou seja, com o lugar do mestre.

Por fim, mesmo que haja alguma coisa em torno do significante latino que se remeta ao imperialismo e a um possível recalque daí advindo, nós da terceira geração, os latino-americanos, pudemos, por nossa condição nos apropriarmos e assim o mudarmos, a nossa, maneira, de tal forma e a tal ponto que hoje muitos de nós temos que fazer um esforço para retomar a história e lembrarmos do porquê de termos sido assim nomeados. Foi esse, aliás, todo o esforço deste artigo. Talvez ele não tenha sido tão original e tendo apenas resgatado alguns traços que esse nome já carregava desde seu surgimento. Porém, de todo modo, o fato de termos sido nomeados como latinos, nos faz, atualmente, em um contexto cotidiano, encarnar esse significante. Para citar um exemplo pessoal, quando cheguei na França, rapidamente me dei conta da força da minha latinidade. Muito frequentemente, após dizer que eu era brasileira, eu era nomeada de latina pelo meu interlocutor: "você é latina", "logo vê-se que você é latina", "eu adoro os latinos como você", etc. Por outro lado, quando estamos na América Latina, não temos a necessidade de nos nomear enquanto tal, nós não chamamos a nós mesmos de latinos porque isso não é uma característica que nos distingue uns dos outros. É atravessando fronteiras e oceanos que essa palavra que já tinha se instalado enquanto substantivo volta a ser um adjetivo 
que tem então por função caracterizar - de modo muitas vezes, fetichista - um povo que, em seu interior, carrega um modo caloroso de ser humano. Hoje, quando pensamos no que é ser latino, pensamos em ser alegre, aberto, receptivo, amigável, gentil, disponível, etc. Na França que, segundo os próprios franceses, é “o país menos latino dos países latinos" escuta-se frequentemente que a latinização de seu povo aumenta junto com as temperaturas e conforme diminui a latitude, ou seja, quanto mais ao sul do país, quanto mais quente e quanto mais perto das fronteiras com a Itália e com a Espanha, mais latinas são as pessoas.

No fim dessa errância por todos os caminhos que levam a Roma, e depois de tantas bifurcações, encontros, desencontros com esse signo, algumas perguntas ainda se colocam: como é que nós, latino-americanos vamos construir daqui em diante nossa relação com nossas origens? De que modo nos reconhecemos e com quem nos identificamos? Qual será o recalcado da nossa colonização? E mais importante, como será seu retorno?

\section{Referências}

ARDÃO, Arturo. Génesis de la idea y el nombre de América Latina. Caracas: Centro de Estudios Latinoamericanos Romulo Gallegos, 1980.

BILBAO, Francisco. Iniciativa de la América. Idea de un Congreso Federal de las Repúblicas, 1856. Disponível em: $<$ http://www.filosofia.org/aut/002/fbb1285.htm>. Acesso em: 22 fev 2021.

BRANDALISE, Carla. O conceito de América Latina: hispano-americamos e a panlatinidade europeia. Cuadernos del CILHA, vol. 14, n. 1, 2013, p. $74-106$.

CAICEDO, José Maria Torres. Las dos Américas (1856). In: El Correo de Ultramar. Paris, 15 de fevereiro de 1857. Disponível em: <www.filosofia.org/hem/185/18570215.htm>. Acesso em: 25 maio 2021.

CALVO, Charles. Recueil Complet de Traites, Conventions, Capitulations, Armistices et Autres Actes Diplomatiques de tous les états de L'Amérique latine, compris entre le golfe du Mexique et le Cap de Horn, depuis l’année 1493 jusquà nos jours. Paris: Librairie de A. Durand, 1862.

CÉSAR, Jules. La Guerre des Gaules. Paris: Flammarion, 1993.

CHEVALIER, Michel. Lettres sur l'Amérique de Nord. Paris: Libraire de Charles Gosselin et Cie., 1836.

DINIZ, Dilma Castelo Branco. O conceito de América Latina: uma visão francesa. Caligrama, Belo Horizonte, v. 12, 2007, p. 129-148.

FARRET, Rafael \& PINTO, Simone Rodrigues. América Latina: da construção de um nome à consolidação da ideia. Topoi, v. 12, jul-dez, 2011, p. 30-42.

F.R. Les hommes de la race latine - Don Mariano E. de Rivero. Revue des Races Latines. Paris, 1859.

FREUD, Sigmund. Contribuição à história do movimento psicanalítico (1914). In: FREUD, Sigmund. Obras Completas, vol. 11. SOUZA, Paulo César de. (Trad.). São Paulo: Companhia das Letras, 2012.

FREUD, Sigmund. O recalque (1915). In: FREUD, Sigmund. Escritos sobre a psicologia do inconsciente. HANNS, Luiz A. et al. (Trad.). Rio de Janeiro: Imago, 2004.

FREUD, Sigmund. O Inconsciente (1915). In: FREUD, Sigmund Obras Completas, vol. 12. SOUZA, Paulo César de. (Trad.). São Paulo: Companhia das Letras, 2010.

FREUD, Sigmund. Conferências Introdutórias à Psicanálise. Conferência 6: Pressupostos e técnicas da interpretação (1916-1917a). In: FREUD, Sigmund Obras Completas, vol. 13. TELLAROLI, Sergio. (Trad.). São Paulo: Companhia das Letras, 2014.

FREUD, Sigmund. Conferências Introdutórias à Psicanálise. Conferência 23: Os cainhos da formação de sintomas (1916-1917b). In: FREUD, Sigmund Obras Completas, vol. 13. TELLAROLI, Sergio. (Trad.). São Paulo: Companhia das Letras, 2014.

FREUD, Sigmund. Psicologia das massas e análise do Eu (1921). In: FREUD, Sigmund Obras Completas, vol. 15. SOUZA, Paulo César de. (Trad.). São Paulo: Companhia das Letras, 2011.

GONZALEZ, Lélia. A categoria político-cultural de amefricanidade. Tempo Brasileiro. Rio de Janeiro, nº. 92/93, janeiro/junho, 1988, p. 69-82. 
GRIMAL, Pierre. La civilisation romaine. Paris: Flamarion, 1981.

GRIMAL, Pierre. Histoire de Rome. Paris: Mille et une nuits, 2003.

HACQUARD, Georges; DAUTRY, Jean.; MAISANI, Olivier. Guide Romain Antique. Paris: Hachette, 2010.

LACAN, Jacques. Função e campo da fala e da linguagem (1953). In: LACAN, Jacques. Escritos. Rio de Janeiro: Zahar, 1998.

LACAN, Jacques. O seminário. Livro 3. As psicoses (1955-1956). Rio de Janeiro: Jorge Zahar, 2010.

LACAN, Jacques. A carta roubada (1957). In: LACAN, Jacques. Escritos. Rio de Janeiro: Jorge Zahar, 1998.

OVÍDIO. Metamorfoses. São Paulo: Editora 34, 2017.

PHELAN, John L. El origen de la idea de latinoamérica. In: ZEA, L. (Comp.) Fuentes de la cultura latinoamericana. Tomo I. México: Fondo de Cultura Económica, p. 461-495, 1993.

ROJAS MIX, Miguel. Los cien nombres de América. Barcelona: Editorial Lumen, 1991.

SAUSSURE, Ferdinand. Curso de Linguística Geral (1916). São Paulo: Cultrix, 1977.

SÊNECA. Consolação a minha mãe Helvia. São Paulo: Atena, 2005.

TISSERAND, Lazare-Murice. Situation de la Latinité. Revue des Races Latines. Paris: 1861.

TITE-LIVE. Histoire romaine. Paris : Les Belles Lettres, 1955.

VIRGÍlIO. Eneida. São Paulo: Editora 34, 2014.

VIRGÍLIO. Géorgiques. Paris : Les Belles Lettres, 1982. 